http:/ /dx.doi.org/10.1590/0104-07072017004220015

\title{
TRAUMA BY TRAFFIC ACCIDENT IN ELDERLY PEOPLE: RISK FACTORS AND CONSEQUENCES ${ }^{1}$
}

\author{
Ana Maria Ribeiro dos Santos², Rosalina Aparecida Partezani Rodrigues ${ }^{3}$, Marina Aleixo Diniz ${ }^{4}$
}

${ }^{1}$ Text extracted from dissertation - Trauma by traffic accident in elderly people: risk factors and consequences, presented in the Programa de Pós-Graduação em Enfermagem Escola de Enfermagem, de Ribeirão Preto (EERP) in the Universidade de São Paulo (USP), 2014.

${ }^{2}$ Ph.D. in Sciences. Professor, Departamento de Enfermagem, Programa de Pós-Graduação em Enfermagem da Universidade Federal do Piauí. Teresina, Piauí, Brasil. E-mail: ana.mrsantos@gmail.com

${ }^{3}$ Ph.D. in Nursing. Professor, Departamento de Enfermagem Geral e especializada, EERP/USP. Ribeirão Preto, São Paulo, Brasil. E-mail: rosalina@eerp.usp.br

${ }^{4}$ Doctoral student. Programa de Pós-Graduação em Enfermagem Fundamental EERP/USP. Ribeirão Preto, São Paulo, Brasil. E-mail: marinadiniz@usp.br

\section{ABSTRACT \\ Objective: to analyze cases of trauma caused by traffic accidents in elderly individuals assisted at a reference municipal emergency hospital in 2010 and 2011. \\ Method: longitudinal retrospective study was developed at an emergency hospital and a Traffic Accidents Repression Station, with 524 elderly individuals. All variables were submitted for descriptive analysis. Risk of involvement in accidents, occurrence of injury and death were determined using relative risk. \\ Results: a statistically significant association was found in accidents with injuries when motorcycles were the vehicle that ran over the individual. Associations were also found between men and the occurrence of accidents, injury and death, mainly among younger elderly individuals. Most of the 524 elderly individuals who suffered an accident were men, married and had elementary school level education. Of these, $78.6 \%$ presented with injuries, with the majority of them being pedestrians. \\ Conclusion: among younger elderly individuals, the possibility of death as a result of the injury was 3.4 times higher in 2010. \\ DESCRIPTORS: Aged. Accidents, traffic. Wounds and injuries. Relative risk. \\ TRAUMA POR ACIDENTE DE TRÂNSITO NO IDOSO: FATORES DE RISCO E CONSEQUÊNCIAS}

\section{RESUMO}

Objetivo: analisar o trauma por acidente de trânsito no idoso, atendido em um hospital municipal de referência em urgência, nos anos de 2010 e 2011.

Método: estudo longitudinal, retrospectivo, desenvolvido em um hospital de urgência e na Delegacia de Repressão aos Crimes de Trânsito, em uma população de 524 idosos. Realizou-se análise descritiva para todas as variáveis. Determinou-se o risco de envolvimento em acidente, ocorrência de lesão e óbito utilizando o risco relativo.

Resultados: verificou-se associação estatisticamente significativa nos acidentes com lesão, quando a motocicleta foi o veículo atropelador. Constatou-se associação entre o sexo masculino, a ocorrência de acidente, lesão e óbito, principalmente entre os idosos mais jovens. Dos 524 idosos acidentados, a maioria era do sexo masculino, casado, com ensino fundamental. Desses, 78,6\% apresentaram lesão, sendo a maior parte pedestre.

Conclusão: entre os idosos mais jovens, a possibilidade de óbito em decorrência da lesão, mostrou-se 3,4 vezes maior no ano de 2010.

DESCRITORES: Idoso. Acidentes de trânsito. Ferimentos e lesões. Risco relativo. 


\section{TRAUMA POR ACCIDENTE DE TRÁNSITO EN ANCIANOS: FACTORES DE RIESGO Y CONSECUENCIAS}

\section{RESUMEN}

Objetivo: analizar los traumas por accidentes de tránsito en ancianos atendidos en Emergencias de hospital municipal de referencia en 2010 y 2011.

Metodo: estudio longitudinal, retrospectivo, realizado en hospital de urgencias y en Delegación de Represión a Crímenes de Tránsito sobre población de 524 ancianos. Se efectuó análisis descriptivo para todas las variables.

Resultados: se determinó riesgo de participación en accidente, ocurrencia de lesión y fallecimiento utilizando riesgo relativo. Se verificó asociación estadísticamente significativa en accidentes con lesión provocada por atropello de motocicleta. Se constató asociación entre sexo masculino, ocurrencia de accidente, lesión y fallecimiento, particularmente entre ancianos menores. De los 524 ancianos accidentados, prevaleció sexo masculino, casados, con escolarización primaria. El 78,6\% presentó lesión, siendo mayoría los peatones.

Conclusión: entre ancianos jóvenes, la posibilidad de fallecimiento derivada de lesión se mostró 3,4 veces mayor en 2010.

DESCRIPTORES: Anciano. Accidentes de tránsito. Heridas y traumatismos. Riesgo relativo.

\section{INTRODUCTION}

Currently, the health care of the elderly is a priority, due to the growth of the elderly population in the world. In France, the increase in the number of elderly people from $7 \%$ to $14 \%$ of the total population occurred in more than a century, while in Brazil this demographic variation will occur in the next two decades. Thus, population aging is a global challenge which needs to be addressed by both developed and developing countries. ${ }^{1}$

The Brazilian elderly population currently accounts for 10 to $19 \%$ of the total population. However, in the year 2050, it will correspond to about 25 to $29 \%$, a figure similar only found in Japan, whose elderly population corresponds to $30 \%$ of the total population. $^{2}$

Parallel to this population growth, it is observed that the elderly are living healthier and remain active for longer. However, the occurrence of trauma has significantly increased in this group, and its management should be seen as a public health problem, which requires preventive action. ${ }^{3}$

Trauma is a phenomenon described as injury from force, which may be accidental, self-imposed or as a result of an act of violence, affecting one or more systems and requiring immediate care. ${ }^{4}$ A systematic review in the United States, which aimed to analyze the rates and predictors of mortality in elderly people with serious injuries based on the available evidence in the literature, concluded that the overall mortality rate in the injured elderly population was higher than in the adult population, noting that older injured elderly adults who were 74 years of age or older had a higher risk of mortality than the younger elderly adults.

In Brazil, the elderly presented the highest mortality rates and hospitalizations due to external causes of the public system in 2008, corresponding to 109 and 650 per 100,000 inhabitants, respectively, while the same rates for the age group from 20 to 59 years were equal to 88 and $430 .^{6}$

However, despite the increase in the incidence of trauma in the population aged 60 and over, few studies seek to identify risk factors capable of preventing complications and mortality in this age group. ${ }^{7}$

Due to all these facts, it was considered necessary to deepen the knowledge in relation to trauma in the elderly population, as a result of traffic, defined by the Brazilian Traffic Code as the use of roads by individuals, vehicles and animals, isolated or in groups, conducted or not for the purposes of movement, stopping, parking and loading or unloading. ${ }^{8}$

Considering these considerations, the objective of this study was to analyze trauma in the elderly due to traffic accidents, who were treated at an emergency hospital between 2010 and 2011.

\section{METHOD}

A retrospective longitudinal study developed in an emergency hospital, referenced in trauma care and in the Delegacia de Repressão aos Crimes de Trânsito, located in the city of Teresina, capital of the State of Piauí, Brazil. The study population consisted of 524 elderly people of both sexes, residents of Teresina, who suffered a traffic accident in the mentioned municipality and were treated at the referral hospital between 2010 and 2011. These years were chosen because all medical records, of the period in question, are already available for consultation at the above-mentioned emergency service.

The data collection was carried out in two stages: the first occurred in the referred emergency hospital, where the medical records of the elderly who suffered a traffic accident between 2010 and 2011 were consulted. The second stage occurred 
in the Delegacia de Repressão aos Crimes de Trânsito of Teresina and the traffic accident records and police inquiries were consulted to accompany the accident information.

The data were collected, using forms which were submitted for content validation conducted by three judges, then analyzed in the Statistical Package for Social Sciences (SPSS) software, version 19.0 where a descriptive analysis of all the variables was performed, including the measures of position and variability for the quantitative variables. The chi-square $(x 2)$ or Fisher's exact tests, as appropriate, were used to test the association between cases of injury and independent variables, with $\mathrm{p}<0.05$ being considered statistically significant.

In order to analyze the risk of involvement in traffic accidents, the occurrence of injury and death among the elderly, the relative risk (RR) was used as a measure of association, considering a $95 \%$ confidence interval (95\% CI), which indicated how the risk of being involved in a traffic accident, suffering injury and death due to the accident was greater among those exposed compared to those not exposed.

The research was approved by the Research Ethics Committee of the University of São Paulo in Ribeirão Preto College of Nursing, under protocol No. 89,092, after authorization approval of the places where the data would be collected.

\section{RESULTS}

The socio-demographic profile of the elderly participants of the study revealed that the mean age of the accident victims was 66.4 years of age $(\mathrm{SD}=5.2)$, a median age of 65 years of age, ranging from 60 to 79 years old for the younger elderly and 84.6 years old $(\mathrm{SD}=4.2)$, median age of 84 years of age, ranging from 80 to 95 years of age among the older elderly.

The majority of injured elderly people (93.7\%) were between 60 and 79 years old. The lowest frequencies were observed in the age groups corresponding to the elderly with a total of $6.3 \%$ of the occurrences of accidents (Table 1).

The majority of the injured elderly were male $(69.1 \%)$, married $(66.8 \%)$ and with elementary level education $(65.3 \%)$.

Concerning the condition of the elderly at the time of the accident, it was verified that the majority of the victims were pedestrians $(42.2 \%)$, with motorcyclists also being highlighted, representing $36.1 \%$ of the cases.

In the analysis of the vehicle involved in the occurrences, it was observed that in $31.3 \%$ of the accidents a motorcycle was the vehicle present at the event. However, there was no record of the vehicle involved in $33.6 \%$ of the accidents. Considering the record of the use of alcohol, it was found that in most cases $(95.4 \%)$, there was no record of the suspected use of this substance among the injured elderly person.

Of the total number of elderly people treated due to a traffic accident, $78.6 \%$ had an injury, an increase in this occurrence was observed when comparing the data for 2010 (73\%) with those recorded in $2011(85 \%)$.

Table 1 - Distribution of the elderly involved in traffic accidents, treated at a referred emergency hospital. Teresina, PI, Brazil, $2010(\mathrm{n}=256) / 2011(\mathrm{n}=268)$

\begin{tabular}{|c|c|c|c|c|c|c|}
\hline \multirow[t]{2}{*}{ Variables } & \multirow[t]{2}{*}{$\begin{array}{l}\text { Average } \\
\left(\mathrm{DP}^{*}\right)\end{array}$} & \multirow[t]{2}{*}{$\begin{array}{l}\text { Median } \\
\left(\mathrm{IC}_{95 \%}^{\dagger}\right)\end{array}$} & \multirow[t]{2}{*}{ Variation } & \multicolumn{3}{|c|}{ Year of accident } \\
\hline & & & & 2010 & 2011 & Total \\
\hline & & & & $\mathbf{n}(\%)$ & $\mathbf{n}(\%)$ & $\mathbf{n}(\%)$ \\
\hline \multicolumn{7}{|l|}{ Elderly } \\
\hline Younger elderly & $66.4(5.2)$ & $65(64 ; 66)$ & {$[60 ; 79]$} & 237 (92.6) & $254(94.8)$ & 491 (93.7) \\
\hline Older elderly & $84.6(4.2)$ & $84(82 ; 85)$ & [80;95] & $19(7.4)$ & $14(5.2)$ & $33(6.3)$ \\
\hline \multicolumn{7}{|l|}{ Sex } \\
\hline Male & & & & $181(70.7)$ & $181(67.5)$ & $362(69.1)$ \\
\hline Female & & & & $75(29.3)$ & $87(32.5)$ & $162(30.9)$ \\
\hline \multicolumn{7}{|l|}{ Marital status } \\
\hline Single & & & & $24(9.4)$ & $47(17.5)$ & $71(13.5)$ \\
\hline Married & & & & $174(68)$ & $176(65.7)$ & $350(66.8)$ \\
\hline Divorced & & & & $19(7.4)$ & $11(4.1)$ & $30(5.7)$ \\
\hline Widowed & & & & $39(15.2)$ & $34(12.7)$ & $73(13.9)$ \\
\hline
\end{tabular}




\begin{tabular}{|c|c|c|c|c|c|c|}
\hline \multirow[t]{2}{*}{ Variables } & \multirow[t]{2}{*}{$\begin{array}{l}\text { Average } \\
\left(\mathrm{DP}^{*}\right)\end{array}$} & \multirow[t]{2}{*}{$\begin{array}{l}\text { Median } \\
\left(\text { IC }_{95 \% \%}^{\dagger}\right)\end{array}$} & \multirow[t]{2}{*}{ Variation } & \multicolumn{3}{|c|}{ Year of accident } \\
\hline & & & & 2010 & 2011 & Total \\
\hline & & & & $n(\%)$ & n(\%) & $\mathbf{n}(\%)$ \\
\hline \multicolumn{7}{|l|}{ Schooling } \\
\hline Illiterate & & & & $54(21.1)$ & $45(16.8)$ & 99 (18.9) \\
\hline Primary school & & & & $168(65.6)$ & $174(64.9)$ & $342(65.3)$ \\
\hline Secondary school & & & & $31(12.1)$ & $45(16.8)$ & $76(14.5)$ \\
\hline Third Level Education & & & & $3(1.2)$ & $4(1.5)$ & $7(1.3)$ \\
\hline \multicolumn{7}{|l|}{ Condition of elderly person } \\
\hline Pedestrian & & & & $108(42.2)$ & $113(42.2)$ & $221(42.2)$ \\
\hline Cyclist & & & & $30(11.7)$ & $20(7.5)$ & $50(9.5)$ \\
\hline Motor cyclist & & & & $81(31.6)$ & $108(40.3)$ & $189(36.1)$ \\
\hline Passenger in automobile & & & & $31(12.1)$ & $20(7.5)$ & $51(9.7)$ \\
\hline Other & & & & $2(0.8)$ & $6(2.2)$ & $8(1.5)$ \\
\hline Ignored & & & & $4(1.6)$ & $1(0.4)$ & $5(1.0)$ \\
\hline \multicolumn{7}{|l|}{ Vehicle involved } \\
\hline Bicycle & & & & $2(0.8)$ & $7(2.6)$ & $9(1.7)$ \\
\hline Motorcycle & & & & $72(28.1)$ & $92(34.3)$ & $164(31.3)$ \\
\hline Automobile & & & & $62(24.2)$ & $62(23.1)$ & $124(23.7)$ \\
\hline Truck & & & & $4(1.6)$ & - & $4(0.8)$ \\
\hline Bus & & & & $6(2.3)$ & $3(1.1)$ & $9(1.7)$ \\
\hline Doesn't apply & & & & $7(2.7)$ & $22(8.2)$ & $29(5.5)$ \\
\hline Ignored & & & & $98(38.3)$ & $78(29.1)$ & $176(33.6)$ \\
\hline Other & & & & $5(2)$ & $4(1.5)$ & $9(1.7)$ \\
\hline \multicolumn{7}{|l|}{ Suspected use of alcohol } \\
\hline Yes & & & & $16(6.2)$ & $8(3)$ & $24(4.6)$ \\
\hline No & & & & $240(93.8)$ & $260(97)$ & $500(95.4)$ \\
\hline \multicolumn{7}{|l|}{ Ocurrence of injury } \\
\hline Yes & & & & $187(73)$ & $225(85)$ & $412(78.6)$ \\
\hline No & & & & $69(27)$ & $43(16)$ & $112(21.4)$ \\
\hline
\end{tabular}

*SD: Standard Deviation; † 95\% CI: 95\% Confidence Interval

In the analysis of the association between cases of injury/trauma and independent variables, there were no statistically significant associations, except for the motorcycle variable being the vehicle involved in the accident ( $p=0.001)$, allowing to state that in traffic accidents with the elderly, when the motorcycle was the vehicle which knocked over the victim, there was a significant increase in the probability of occurrence of injury (Table 2).

Table 2 - Association between the variables of the study and the occurrence of injury in the elderly person involved in an accident. Teresina, PI, Brazil, 2010-2011

\begin{tabular}{|c|c|c|c|c|c|c|c|c|c|}
\hline \multirow[b]{2}{*}{ Variable } & \multicolumn{3}{|c|}{ Ocurrence of Injury 2010} & \multicolumn{3}{|c|}{ Ocurrence of Injury 2011} & \multicolumn{3}{|c|}{$\begin{array}{c}\text { Ocurrence of Injury } \\
2010 / 2011\end{array}$} \\
\hline & $\begin{array}{l}\text { Yes } \\
\mathbf{n}(\%)\end{array}$ & $\begin{array}{l}\text { Total } \\
\text { n(\%) }\end{array}$ & p-value* & $\begin{array}{l}\text { Yes } \\
\mathbf{n}(\%)\end{array}$ & $\begin{array}{l}\text { Total } \\
\mathbf{n}(\%)\end{array}$ & $\begin{array}{c}\text { p-value } \\
\text { n(\%) }\end{array}$ & $\begin{array}{c}\text { Yes } \\
\mathbf{n}(\%)\end{array}$ & Total & p-value ${ }^{*}$ \\
\hline \multicolumn{10}{|l|}{ Elderly } \\
\hline Younger elderly person & $175(73.8)$ & $237(100)$ & 0.313 & $214(84.3)$ & $254(100)$ & 0.476 & $389(79.2)$ & 491(100) & 0.196 \\
\hline Older elderly person & $12(63.2)$ & 19(100) & - & 11(78.6) & $14(100)$ & - & $23(69.7)$ & $33(100)$ & - \\
\hline
\end{tabular}




\begin{tabular}{|c|c|c|c|c|c|c|c|c|c|}
\hline \multirow[b]{2}{*}{ Variable } & \multicolumn{3}{|c|}{ Ocurrence of Injury 2010} & \multicolumn{3}{|c|}{ Ocurrence of Injury 2011} & \multicolumn{3}{|c|}{$\begin{array}{c}\text { Ocurrence of Injury } \\
2010 / 2011\end{array}$} \\
\hline & $\begin{array}{l}\text { Yes } \\
\mathrm{n}(\%)\end{array}$ & $\begin{array}{l}\text { Total } \\
\mathbf{n}(\%)\end{array}$ & p-value* & $\begin{array}{c}\text { Yes } \\
\text { n(\%) }\end{array}$ & $\begin{array}{l}\text { Total } \\
\mathbf{n}(\%)\end{array}$ & $\begin{array}{c}\text { p-value } \\
\mathbf{n}(\%)\end{array}$ & $\begin{array}{l}\text { Yes } \\
\text { n(\%) }\end{array}$ & Total & p-value* \\
\hline \multicolumn{10}{|l|}{ Gender } \\
\hline Male & $129(71.3)$ & 181(100) & 0.32 & $151(83.4)$ & $181(100)$ & 0.733 & $280(77.3)$ & $362(100)$ & 0.286 \\
\hline Female & $58(77.3)$ & $75(100)$ & - & $74(85.1)$ & $87(100)$ & - & 132(81.5) & 162(100) & - \\
\hline \multicolumn{10}{|l|}{ Marital Status } \\
\hline Single & $19(79.2)$ & $24(100)$ & 0.478 & $40(85.1)$ & $47(100)$ & 0.813 & $59(83.1)$ & $71(100)$ & 0.323 \\
\hline Married & $126(72.4)$ & 174(100) & 0.739 & $149(84.7)$ & $176(100)$ & 0.664 & $275(78.6)$ & $350(100)$ & 0.966 \\
\hline Divorced & $13(68.4)$ & 19(100) & 0.637 & $9(81.8)$ & $11(100)$ & 0.691 & $22(73.3)$ & $30(100)$ & 0.466 \\
\hline Widowed & $29(74.4)$ & $39(100)$ & 0.841 & $27(79.4)$ & $34(100)$ & 0.44 & $56(76.7)$ & 73(100) & 0.667 \\
\hline \multicolumn{10}{|l|}{ Education } \\
\hline Illiterate & $41(75.9)$ & $54(100)$ & 0.591 & $38(84.4)$ & $45(100)$ & 0.922 & $79(79.8)$ & $99(100)$ & 0.752 \\
\hline Primary School & $128(76.2)$ & 168(100) & 0.117 & $148(85.1)$ & $174(100)$ & 0.504 & $276(80.7)$ & $342(100)$ & 0.112 \\
\hline Secondary school & $17(54.8)$ & $31(100)$ & 0.015 & $37(82.2)$ & $45(100)$ & 0.728 & $54(71.1)$ & $76(100)$ & 0.082 \\
\hline Third level education & $1(33.3)$ & $3(100)$ & 0.178 & $2(50)$ & $4(100)$ & 0.122 & $3(42.9)$ & $7(100)$ & 0.041 \\
\hline \multicolumn{10}{|l|}{ Condition of elderly } \\
\hline Pedestrian & $81(75)$ & 108(100) & 0.547 & 102(90.3) & $113(100)$ & 0.016 & $183(82.8)$ & 221(100) & 0.046 \\
\hline Cyclist & $25(83.3)$ & $30(100)$ & 0.177 & $17(85)$ & $20(100)$ & 0.999 & $42(84)$ & $50(100)$ & 0.330 \\
\hline Motorcyclist & $56(69.1)$ & $81(100)$ & 0.337 & $85(78.7)$ & $108(100)$ & 0.054 & 141(74.6) & 189(100) & 0.092 \\
\hline Passenger in automobile & $22(71)$ & $31(100)$ & 0.781 & $16(80)$ & $20(100)$ & 0.539 & $38(74.5)$ & $51(100)$ & 0.450 \\
\hline Other & $1(50)$ & $2(100)$ & 0.467 & $4(66.7)$ & $6(100)$ & 0.247 & $5(62.5)$ & $8(100)$ & 0.377 \\
\hline Ignored & $2(50)$ & $4(100)$ & 0.294 & $1(100)$ & $1(100)$ & 0.999 & $3(60)$ & $5(100)$ & 0.291 \\
\hline \multicolumn{10}{|l|}{ Vehicle involved } \\
\hline Bicycle & $2(100)$ & $2(100)$ & 0.999 & $7(100)$ & $7(100)$ & 0.602 & $9(100)$ & $9(100)$ & 0.216 \\
\hline Motorcycle & $61(84.7)$ & $72(100)$ & 0.008 & $82(89.1)$ & $92(100)$ & 0.095 & $143(87.2)$ & 164(100) & 0.001 \\
\hline Automobile & $41(66.1)$ & $62(100)$ & 0.158 & $55(88.7)$ & $62(100)$ & 0.245 & $96(77.4)$ & 124(100) & 0.708 \\
\hline Truck & $3(75)$ & $4(100)$ & 0.999 & - & - & - & $3(75)$ & $4(100)$ & 0.999 \\
\hline Bus & $6(100)$ & $6(100)$ & 0.195 & $2(66.7)$ & $3(100)$ & 0.410 & $8(88.9)$ & $9(100)$ & 0.692 \\
\hline Does not apply & $6(85.7)$ & $7(100)$ & 0.678 & $16(72.7)$ & $22(100)$ & 0.137 & $22(75.9)$ & $29(100)$ & 0.709 \\
\hline Ignored & $65(66.3)$ & $98(100)$ & 0.056 & $60(76.9)$ & $78(100)$ & 0.044 & $125(71)$ & 176(100) & 0.003 \\
\hline Other & $3(60 \%)$ & $5(100 \%)$ & 0.614 & $3(75)$ & $4(100)$ & 0.505 & $6(66.7)$ & $9(100)$ & 0.411 \\
\hline \multicolumn{10}{|l|}{ Suspected use of alcohol } \\
\hline Yes & $11(68.8)$ & $16(100)$ & 0.772 & $7(87.5)$ & $8(100)$ & 0.999 & $18(75)$ & $24(100)$ & 0.657 \\
\hline No & $176(73.3)$ & $240(100)$ & - & $218(83.8)$ & $260(100)$ & - & $394(78.8)$ & $500(100)$ & \\
\hline
\end{tabular}

* Chi-square test or Fisher's exact test

The relative risk related to gender was determined by age group, analyzing the involvement in the accident, the occurrence of injury or death of the elderly, and using data from the Demographic Census $^{9}$ as the reference value for the population exposed to the trauma in the year 2010 and the population estimate of the Instituto Brasileiro de Geografia e Estatística (IBGE), stratified by gender and age group by the Department of Informatics of SUS for the population exposed in 2011. ${ }^{10}$
Table 3 shows that males aged between 60 and 79 years of age and 80 years and older presented with a $3.3(\mathrm{CI}=2.501-4.385)$ and $4.0(\mathrm{CI}=1.474-$ $10,221)$ higher chance to be involved in traffic accidents in 2010 and a 2.9 (CI=2.192-3.713) and 3.3 (CI=1.101-9.816) higher chance in 2011.

Regarding the occurrence of injury, the relative risk coefficients were also significant in males in younger and older elderly people in the two years studied, and in 2010 it was found that the chances 
were $3.1(\mathrm{CI}=2.21-4.202)$ and $3.8(\mathrm{CI}=1.078-11.907)$ greater in occurrence after the accident. However, in 2011, in the same sex, this risk was significant only among the younger elderly, corresponding to $2.8(\mathrm{CI}=2,145-3,809)$.
The values found for the relative risk of death in the elderly with injuries were significant in the younger elderly, showing a $3.4(\mathrm{CI}=1,066-10,842)$ higher chance in the younger elderly person in 2010. However, in 2011, this risk was not significant in the age groups examined.

Table 3 - Distribution of elderly in traffic accidents, according to relative risk of involvement in accident, occurrence of injury and death, by sex according to age group. Teresina-PI, Brazil, 2010-2011

\begin{tabular}{|c|c|c|c|c|c|c|c|c|c|}
\hline \multirow{2}{*}{ Variable } & \multirow{2}{*}{ Sex* } & \multicolumn{2}{|c|}{$n^{0}$ of events } & \multicolumn{2}{|c|}{$n^{0}$ of exposed } & \multicolumn{2}{|c|}{ Incidence } & \multicolumn{2}{|c|}{$\mathrm{RR} †\left(\mathrm{CI}_{95 \%}\right)$} \\
\hline & & 2010 & 2011 & 2010 & 2011 & 2010 & 2011 & 2010 & 2011 \\
\hline \multicolumn{10}{|l|}{ Involvement in accident } \\
\hline \multirow{2}{*}{ Younger elderly person } & M & 168 & 172 & 24989 & 25239 & 0.67 & 0.68 & \multirow{2}{*}{$3.3(2.501-4,385)$} & \multirow{2}{*}{$2.9(2.192-3.713)$} \\
\hline & $\mathrm{F}$ & 69 & 82 & 33986 & 34326 & 0.20 & 0.24 & & \\
\hline \multirow{2}{*}{ Older elderly person } & M & 13 & 9 & 3466 & 3626 & 0.38 & 0.25 & \multirow{2}{*}{$4.0(1.474-10.221)$} & \multirow{2}{*}{$3.3(1.101-9.816)$} \\
\hline & $\mathrm{F}$ & 6 & 5 & 6209 & 6622 & 0.10 & 0.08 & & \\
\hline \multicolumn{10}{|l|}{ Ocorrence of injury } \\
\hline \multirow{2}{*}{ Younger elderly person } & M & 121 & 145 & 24989 & 25239 & 0.48 & 0.57 & \multirow{2}{*}{$3.1(2.21-4.202)$} & \multirow{2}{*}{$2.8(2.145-3.809)$} \\
\hline & $\mathrm{F}$ & 54 & 69 & 33986 & 34326 & 0.16 & 0.20 & & \\
\hline \multirow{2}{*}{ Older elderly person } & M & 8 & 6 & 3466 & 3626 & 0.23 & 0.17 & \multirow{2}{*}{$3.8(1.078-11.907)$} & \multirow{2}{*}{$2.2(0.668-7.186)$} \\
\hline & $\mathrm{F}$ & 4 & 5 & 6209 & 6622 & 0.06 & 0.08 & & \\
\hline \multicolumn{10}{|l|}{ Death } \\
\hline \multirow{2}{*}{ Younger elderly person } & M & 10 & 10 & 24989 & 25239 & 0.04 & 0.04 & \multirow{2}{*}{$3,4(1.066-10.842)$} & \multirow{2}{*}{ 2.7(0.93-7.959) } \\
\hline & $\mathrm{F}$ & 4 & 5 & 33986 & 34326 & 0.01 & 0.01 & & \\
\hline \multirow{2}{*}{ Older elderly person } & M & - & 2 & 3466 & 3626 & - & 0.06 & & \multirow{2}{*}{ 4) } \\
\hline & $\mathrm{F}$ & - & 1 & 6209 & 6622 & - & 0.02 & 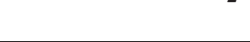 & \\
\hline
\end{tabular}

*M: Male; F: Female; †RR: Relative Risk; CI95\%: ‡Confidence Interval of 95\%

\section{DISCUSSION}

The prevalence of injury among elderly people involved in accidents was considered high. However, the results obtained resemble those identified in national and international studies, which report higher mortality and hospitalizations due to external causes in the elderly population. ${ }^{5-6}$ This fact requires the planning of specific interventions for this population, and the possibility of effective participation of nurses in the development of preventive and educational guidelines for the elderly in primary care.

Similar results in relation to age were also observed in national studies that investigated trauma in the elderly, indicating the presence of characteristics of the younger adult population, among these individuals, ${ }^{7,11-12}$ a fact observed in this study, which evidenced a predominance of cases in the range from 60 to 79 years of age. Investigations also confirm the highest proportion of victims as male. ${ }^{6,12}$

However, in relation to the occurrence by sex, a study of the epidemiology of unintentional injury in Swedish elderly identified a higher incidence in females. ${ }^{13}$ However, in this study the mechanisms of trauma were analyzed together, and falling in the domestic environment was the most frequent accident in the studied populations. Perhaps, there was a higher incidence of trauma among women, because they were more restricted to the home. Regarding the prevalence of trauma, in relation to marital status, it was found that married elderly people were the majority, which can also be seen in the results of a retrospective study, based on the analysis of secondary data in a general hospital in the interior of São Paulo, which identified the socio-demographic profile of the elderly victims of trauma. ${ }^{14}$

As for education, the highest frequency of trauma occurred in the elderly who had an elementary level education, corroborating the results found in a Brazilian study comparing the individual attributes, outcome and types of accidents and violence between the elderly and adults, and identified that the majority of the elderly people had lower education levels. ${ }^{6}$ A possible explanation for the higher prevalence 
of trauma among the elderly with lower education found in the present study is due to the greater possibility of a precarious socioeconomic situation, with more exposure to risks, thus making the elderly people of the study more vulnerable to being involved in a traffic accident.

Concerning the condition of the elderly at the time of the accident, the highest frequency in this study occurred among pedestrians, although those found among motorcyclists is also significant. The vulnerability of the elderly in emergencies is partly due to the deterioration of the intrinsic capacity generally associated with aging, as well as to the characteristics of the environment. Thus, minor deficiencies compensated in various ways in the normal environment of the elderly, quickly become a major burden in an emergency. ${ }^{2}$

In Brazil, a study points out the vulnerability of elderly pedestrians to traffic accidents. Researchers who examined emergency services in 23 capitals and in the Federal District identified that the elderly person was three times more likely to be knocked over than a younger person. ${ }^{6}$

Another study carried out with data from the Surveillance of Violence and Accidents (VIVA) in emergency services of the Brazilian Unified Health System (SUS) in Brazilian capitals in 2011 found that, with the exception of one elderly person, all others were pedestrians. ${ }^{15}$

Similarly, research carried out with data on the surveillance of external causes of a Hospital Epidemiology Center in a general tertiary hospital in the interior of the São Paulo State, also showed that being knocked over represented the second mechanism of trauma among the elderly studied. ${ }^{14}$

Thus, it is possible to verify that the vulnerability of the elderly population to traffic accidents, essentially as pedestrians, is probably due to the inherent limitation in the aging process, as well as poor public traffic conditions, the possibility of inappropriate attitudes of these users, such as driving over pedestrian crossings or driving through a red traffic light. ${ }^{6-7,15}$ In the context of this study, due to the data being secondary, it was not possible to analyze the participation of factors such as public road conditions and attitudes of the elderly at the time of the accident, due to most of the examined documents not containing this information.

However, it is known that the aging process implies a compromise of the functional capacity that can implicate in a situation of greater vulnerability and, consequently, of greater risk. ${ }^{16}$
The cities of Brazil had a disorderly growth, with an increase in the amount of cars, bicycles and motorcycles. This is detrimental to the most vulnerable population, such as the disabled and the elderly, who have specific conditions for their mobility in large cities, which can lead to them being the biggest victims of traffic accidents.

Accidents are recognized as fatalities in several countries, hiding the government's omission from public road infrastructure and roads, as well as carelessness and negligence of the users with respect to traffic safety laws and regulations. This fact makes it possible for many injuries due to accidents not to be prevented or minimized by attitudes such as the use of seat belts, traffic education for pedestrians, intensification of control measures, as well as adequate signposting of roads and educational campaigns regarding the increased risk of traffic accidents. ${ }^{17}$

In fact, motorcycles are increasingly used by the population because they are affordable and easy to maintain, as well as agile in both traffic jams of the city and the precarious rural roads of the municipality. As for the fact that the vehicle is the most involved in accidents with an injury $(p=0.001)$, it is inferred that the elderly, due to visual impairment and restricted mobility, underestimate the speed of the vehicle, and cannot cross the road in the expected time, resulting in collision and, consequently, trauma. A study carried out in Campinas showed that motorcycles were responsible for the highest rates of knocking over people, corresponding to 66.7 road accidents / 1,000 accidents, as well as road accidents followed by death, accounting for a total of four deaths / 1,000 accidents. ${ }^{18}$

Regarding the lack of records of some accident data found in the present study, other national publications have warned that only through a safe and integrated information system can it be possible to plan and develop prevention, care and rehabilitation programs for the elderly victims. ${ }^{4,19}$

Regarding the recorded suspected alcohol use, there was a high frequency of non-recording of this occurrence in cases of trauma. In a US study, which analyzed the prevalence of alcohol and other drugs among fatally injured drivers, it was observed that despite the decrease in alcohol-related traffic accidents, this drug remains the most commonly detected drug in $40 \%$ of drivers who were fatally injured, who die within an hour after the accident.

A Brazilian study comparing the care for violence and accidents in the elderly and adults found a similar result to that found in the present study, noting that alcohol consumption was the attribute that 
presented the greatest age difference among all the analyzed patients, being lower among the elderly. ${ }^{6}$

Thus, the results of this study demonstrate that the situation in this specific region of the country does not differ from that found in the other studies analyzed in relation to the vulnerability of the elderly pedestrians, demonstrating the need to plan and implement specific interventions directed to this population group. The condition of the injured elderly according to sex is highlighted, because only as car passengers, men and women present a frequency of similar cases, in the other categories men always represent the greater part, which is attributed to a greater male participation in this age group in the social environment.

In the reality of the health care of the elderly in the country, the care for the injured elderly can be aggravated by the lack of structure in the emergency services to meet the specifics of this population group. Research that evaluated the access and use of health plan services, expressed through the complaints of the beneficiaries, that the elderly were the population group that proportionally, presented more complaints, with assistance coverage being the most frequent complaint. ${ }^{21}$

Based on the relative risk results, it is inferred that being an elderly male is a risk factor for the involvement in a traffic accident, occurrence of injury after the accident and death, as a result of the injury caused by the collision. Trauma and violence unequally affect males when compared to females. A study that analyzed the profile of the fatal victims of traffic accidents in Minas Gerais, found that the coefficient of mortality for the age group of 60 years and over had more prevelance, with fatal accidents being more prevalent in males, showing that for each victim of fatality, four male deaths occurred. ${ }^{22}$ Another investigation that estimated the incidence of traffic accidents among elderly Koreans also found that this proportion was higher among men, and in women, it tends to decrease with increasing age. ${ }^{23}$

A North American study that examined accidents involving being knocked down by cars in Southeastern Wisconsin which aimed to characterize populations and the pattern of injury, discovered that the mortality rate was higher among the elderly. As pedestrians, this group had a rate that was twice which was found among non-elderly patients, however the trauma severity scale had a similar score at the time of admission. ${ }^{24}$

It is noted that there is an indication of planning and adoption of traffic-related measures to encourage the displacement of vulnerable users, in order to prevent and control the frequency of accidents, especially in the elderly, thus providing them with a healthier and more active life.

In the present study, as a consequence of the traffic accident, considering the cases in which the injury occurred, it was found that there was a higher frequency of immobilizations (47.7\%); However, it is noteworthy that, in $39.5 \%$ of cases of injury, no record was found regarding the consequences of the accident.

Most elderly people who survive road traffic accidents and violence are temporarily or permanently disabled. A study developed in an emergency department of São Paulo found that the severity of the trauma negatively influences the functional capacity. Thus, the lower the severity of the trauma, the greater the functional independence of the elderly.

Thus, issues related to the care and rehabilitation of victims of accidents and violence in this age group need to be considered, such as the need for more frequent hospitalization, longer hospitalization and rehabilitation, which generates higher costs for the health system. ${ }^{7}$

Understanding trauma in the elderly population can provide the health team, in which nurses are part of, to plan strategies and to provide a more specific care to this population, contributing to the prevention of these events, as well as the reduction of temporary or permanent sequelae, with the aim of balancing the health system as a whole. ${ }^{11}$

\section{CONCLUSION}

From the total 524 elderly people who were involved in accidents, the majority were male, married and with an elementary level of school education. Of these, $78.8 \%$ presented injuries, with the majority being pedestrians. It was found that when the motorcycle was the vehicle involved in the accident the likelihood of injury was significantly increased. Among the consequences, immobilization corresponded to 47.7 of the cases.

The results of the study showed an association between the male sex and the occurrence of accidents, injuries and death in almost all situations and age groups examined. It is noteworthy that in the younger age group, the possibility of death due to the injury caused by the accident was 3.4 times higher in 2010.

It is necessary to stimulate the formation of respectful attitudes to the elderly, investing in the construction of an accessible and inclusive urban design, which allows the interaction between gen- 
erations. There is also a need for education and awareness in traffic, with appropriate interventions aimed mainly at vulnerable users of public roads, making it possible for everyone and the elderly in particular to have a universal right to travel safely.

The study presented limitations regarding the analysis of the risks in relation to the factors involved in the accidents, due to lack of records of some information in the organizations in which the data were collected. In this perspective, other studies should be conducted, because the information on morbidity and mortality due to violent causes in this population group is an essential condition for the real dimensioning of the problem and adoption of appropriate protection measures.

\section{Acknowledgements}

The Coordenação de Aperfeiçoamento de Pessoal de Nivel Superior (Capes) in the Interinstitutional Doctoral Project between the Postgraduate Program in Fundamental Nursing of the University of São Paulo in Ribeirão Preto College of Nursing with the Federal University of Paraíba and the Federal University of Piauí, Brazil.

\section{REFERÊNCIAS}

1. Veras RP. Experiências e tendências internacionais de modelos de cuidado para com o idoso. Ciênc Saúde Coletiva. 2012; 17(1):231-8.

2. Organización Mundial de la Salud (OMS). Informe mundial sobre el envejecimiento y la salud. Genebra (CH): Organización Mundial de la Salud; 2015 [cited 2016 Apr 08]. Available from: http://apps.who.int/iris/ bitstream/10665/186466/1/9789240694873_spa.pdf

3. Vicente FR, Santos SMA. Avaliação multidimensional dos determinantes do envelhecimento ativo em idosos de um município de Santa Catarina. Texto Contexto Enferm [Internet]. 2013 Abr-Jun [cited 2016 Apr 08]; 22(2):370-8. Available from: http://www.scielo.br/ $\mathrm{pdf} / \mathrm{tce} / \mathrm{v} 22 \mathrm{n} 2 / \mathrm{v} 22 \mathrm{n} 2 \mathrm{a} 13$

4. Oliveira FMRL, Fernandes MGM, Barbosa KTF, Pereira MA, Santos KFO, Nunes TB. Caracterização do trauma em idosos atendidos em serviço de atendimento móvel de urgência. Rev Rene. 2013; 14(5):945-50.

5. Hashmi A, Ibrahim-Zada I, Rhee P, Aziz H, Fain MJ, Friese RS, Bellal J. Predictors of mortality in geriatric trauma patients: a systematic review and meta-analysis. J Trauma Acute Care Surg. 2014; 76(3):894-901.

6. Luz TCB, Malta DC, Sá NNB, Silva MMA, Lima-Costa MF. Violências e acidentes entre adultos mais velhos em comparação aos mais jovens: evidências do Sistema de Vigilância de Violências e Acidentes (VIVA), Brasil. Cad Saúde Pública. 2011; 27(11): 2135-42.

7. Rodrigues J, Ciosak SI. Idosos vítimas de trauma: análise de fatores de risco. Rev Esc Enferm USP. 2012; 46(6):1400-5.

8. Brasil. Lei n ${ }^{\circ} 9.503$, de 23 de setembro de 1997: dispõe sobre Código de Trânsito Brasileiro [Internet]. Brasília (DF): DENATRAN; 2008 [cited 2012 Jan 10]. Available from: http://www.denatran.gov.br/publicacoes/ download/ctb.pdf

9. Instituto Brasileiro de Geografia e Estatística (IBGE). Sinopse dos resultados do censo 2010 [Internet]. 2010. [cited 2013 Ago 6]. Available from: http://www. censo2010.ibge.gov.br/sinopse/webservice

10. Ministério da Saúde (BR). Estimativas populacionais enviadas para o TCU, estratificadas por idade e sexo pelo MS/SGEP/DATASUS. 2011 [cited 2011 Oct 13]. Available from: http://www2.datasus.gov.br/ DATASUS/index.php?area $=0206 \& V O b j=h t t p: / /$ tabnet.datasus.gov.br/cgi/deftohtm.exe?ibge/cnv/pop

11. Silva HC, Pessoa RL, Menezes RMP. Trauma em idosos: acesso ao sistema de saúde pelo atendimento pré-hospitalar móvel. Rev Latino-Am Enfermagem [Internet]. 2016 [cited 2016 Apr 08]; 24: e2690. Available from: http://www.scielo.br/pdf/rlae/ v24/pt_0104-1169-rlae-24-02690.pdf

12. Parreira JG, Farrath S, Soldá SC, Perlingeiro JAG, Assef JC. Análise comparativa das características do trauma entre idosos com idade superior e inferior a 80 anos. Rev Col Bras Cir. 2013; 40(4): 269-74.

13. Saveman BI, Björnstig U. Unintentional injuries among older adults in northern Sweden - a one-year population-based study. Scand J Caring Sci. 2011 Mar; 25(1):185-93.

14. Degani GC, Pereira Júnior GA, Rodrigues RAP, Luchesi BM, Marques S. Idosos vítimas de trauma: doenças preexistentes, medicamentos em uso no domicílio e índices de trauma. Rev Bras Enferm. 2014; 67(5):759-65.

15. Freitas MG, Bonolo PF, Moraes EN, Machado CJ. Idosos atendidos em serviços de urgência no Brasil: um estudo para vítimas de quedas e de acidentes de trânsito. Ciênc Saúde Coletiva. 2015; 20(3):701-12.

16. Macedo AM, Cerchiari EA, Alvarenga MR, Faccenda O, Oliveira NA. Avaliação funcional de idosos com déficit cognitivo. Acta Paul Enferm. 2012; 25(3):358-63.

17. Brandão GCG, Barrêto AJR, Gaspar JCG, Trindade RFC, Vaz NLF, Oliveira MAC. Acidentes e violências: um retrato das ocorrências nos serviços de atendimento a urgências e emergências. Cad Saúde Colet. 2014; 22(1):2-7

18. Marin-Leon L, Belon AP, Barros MBA, Almeida SDM, Restitutti MC. Tendência dos acidentes de trânsito em Campinas, São Paulo, Brasil: importância crescente dos motociclistas. Cad Saúde Pública. 2012; 28(1):39-51. 
19. Oliveira NLB, Sousa RMC. Ocorrências de trânsito com motocicleta e sua relação com a mortalidade. Rev Latino-Am Enfermagem. 2011; 19(2):403-10.

20. Brady JE, Li G. Prevalence of alcohol and other drugs in fatally injured drivers. Addiction, 2013; 108(1):104-14.

21. Vieira Junior WM, Martins M. Idosos e planos de saúde no Brasil: análise das reclamações recebidas pela Agência Nacional de Saúde Suplementar. Ciênc saúde Coletiva. 2015; 20(12):3817-26.

22. Camargo FC, Iwamoto HH. Vítimas fatais e anos de vida perdidos por acidentes de trânsito em Minas Gerais, Brasil. Esc Anna Nery. 2012; 16(1):141-6.
23. Hong K, Lee KM, Jang SN. Incidence and related factors of traffic accidents among the older population in a rapidly aging society. Arch Gerontol Geriatr. 2015; 60(3):471-7.

24. Mcelroy LM, Juern JJ, Bertleson A, Xiang Q, Szabo A, Weigelt J. A single urban center Experience with adult pedestrians struck by motor vehicles. WMJ. 2013; 112(3):117-22.

25. Maeshiro FL, Lopes MC, Okuno MF, Camapanharo CR, Batista RE. Capacidade funcional e a gravidade do trauma em idosos. Acta Paul Enferm. 2013; 26(4):389-94. 